\title{
ENABLING TRANSFORMATIVE INCLUSIVE LEARNING PEDAGOGIES OF PRESERVICE TEACHERS IN MULTICULTURAL HIGHER LEARNING CONTEXTS
}

\author{
June Palmer ${ }^{1}$, Rantsie Kgothule ${ }^{2}$, Gregg Alexander ${ }^{1}$, \& Edwin de Klerk ${ }^{3}$ \\ ${ }^{I}$ Postgraduate Studies in Education, Central University of Technology, Free State (South Africa) \\ ${ }^{2}$ School of Education Studies, University of the Free State (South Africa) \\ ${ }^{3}$ School of Education, Sol Plaatje University (South Africa)
}

\begin{abstract}
Several studies echo the role of participation and interaction in learning activities as crucial to valorise all students equally. Inclusive pedagogy should recognize the disputed nature of inclusive education and the subsequent unpredictability in teaching practices as a means of identifying students requiring additional learning support particularly amid the COVID-19 pandemic. Such variability raises significant questions about the nature and value of educational provision, around the globe, but particularly in the South African multicultural higher learning context. Having applied a transformative learning methodology this paper explores the influence of inclusive learning pedagogies in shaping preservice teachers' repertoires in multicultural higher learning contexts. The findings suggest that transformative learning promotes specific practices such as trusting relationships within the learning context and an appreciation for diversity and inclusivity, opportunities for critical reflection, shared and collective learning, and transformative leadership development. Ultimately, when circumstances permit, transformative preservice teachers move toward a frame of reference that is more self-reflective, integrative and inclusive of experience. In conclusion we suggest that stakeholders in higher education contexts consider creating institutional spaces for preservice teachers to change their frame of reference in approaching their own teaching and learning repertoires in transformative and inclusive ways.
\end{abstract}

Keywords: Multicultural higher learning context, preservice teacher, Inclusive learning pedagogy, transformative learning theory.

\section{Introduction}

In shaping learning, preservice teachers' knowledge of inclusive practice and employing transformative learning practices become all important. Sustaining preservice teachers' commitment to inclusive practices through teacher leadership while enabling them to identify barriers to learning and catering to the learning support needs of their learners are some of the key aspects HEIs should address. This paper supports the 4IR requirement of "accelerating workforce reskilling" (Penprase, 2019) by (1) promoting the increase of tech-enhanced and online and education within Higher Education Institutions (HEIs), (2) educating students with varied learning experiences, and creating platforms within their learning environments to accommodate innovative technological skills that may improve the learning experiences of all learners. More importantly, these settings should adequately (3) prepare preservice teachers to thrive in learning amid global pandemics through transformative learning modalities such as merged modes of teaching and optimization of online and flipped courses. In so doing, it will ensure more resourceful knowledge settings that can adjust to the multiplicity of student training needs to give more modularity and flexibility of educational programmes.

As such, this paper addresses the question: How may HEIs prepare preservice teachers to implement transformative learning pedagogies to become transformative change agents in multicultural higher learning contexts? 


\section{Theoretical framework}

In this progressively globalised education environment, HEIs have an obligation to ensure that students are not only taught about local or national issues, but that they obtain knowledge about educational trends around the globe, improve their critical intellectual abilities to enable them to have a purposeful role in extremely multifaceted and challenging societies. In this paper, the latter notion fits well into our thinking of applying transformative learning (TL).

TL signifies "developing leadership attributes and its purpose is to produce enlightened change agents" (Frenk et al. 2010, 6). Thus, the result of transformative learning aims at ensuring that individuals have more inclusive insights of the world, the capability to distinguish between various information regarding society, better openness to various viewpoints, and the capacity to incorporate diverse scopes of individual experience into significant and all-inclusive relationships (Mezirow, 1991). TL theory envisions that HEIs will ensure that students apply critical thinking, contest their own expectations, and assist them develop open and inclusive perceptions (Banks \& Banks, 2004).

To this end, TL requires that HEIS involve students (and preservice teachers in particular) "in mentorship, leadership or community development programs to apply their perspectives, intercultural skills, and global knowledge to make them more inclusive, discriminating, open, reflective, and emotionally able to change" (Mezirow, 2003, 58-59). In so doing, HEIs may help students to, "develop their power to perceive critically the way they exist in the world with which and in which they find themselves; they come to see the world not as a static reality, but as a reality in process and transformation" (Freire, 1970, 83).

\section{Discussion: Our point of departure}

Figure 1. Preservice teachers' as transformative change agents.

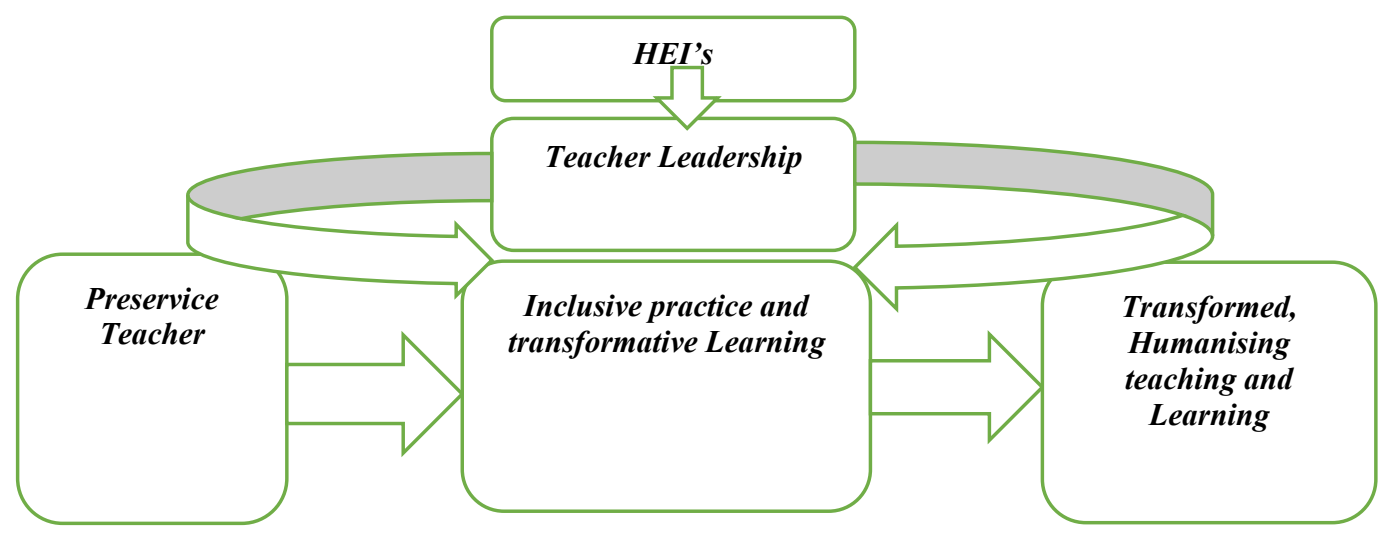

For decades, TL was regarded as something more empowering, thoughtful and more critical than other practices of learning. The potential of TL is that it helps individuals to critically move beyond those apparently self-evident conventions that governs individual thinking, actions and feeling that have been unquestioningly adopted through education and socialization (Hoggan, Mälkki \& Finnegan, 2017). According to Kasworm \& Bowles (2012), a significant intervention strategy to support transformative learning may be indicated as, "the development of self-reflection, an emotional capability to openness, and critical disjuncture" (p. 392). For preservice teachers in HEIs, the aforementioned intervention strategy may include a deliberate improvement of self-reflection through inter alia, thoughtful journals, articles, blogs, or experimental activities such as role-playing aiming to solve confusing problems, engaging in cultural experiences that requires that attention be given to issues such as privilege, race, class, power and gender. Consequently, Kasworm and Bowles's (2012) intervention strategy may be regarded as significant because it may assist learners to scrutinize their expectations, worldviews as well as previous experiences.

These strategies, we contend, are some of the salient features to developing preservice teachers as competent teacher leaders. In enhancing leadership ability, HEIs should acknowledge the learning support needs of preservice teachers to equip them to hold a frame of reference that is enabling in the way that they approach their own teaching and learning repertoires in transformative and inclusive ways. This paper proposes that inclusive practice in HEIs may be successfully accomplished by: 


\subsection{Increasing online and tech-enhanced teaching within HEIs}

Covid-19 necessitated a rethinking of teaching within HEIs, implying that the physical classroom is not accessible in the case of challenges such as pandemic outbreaks (Mpungose, 2020). A turn to online teaching has become more than just an option and may be regarded as an instrument that can make teaching practices more flexible, innovative and student-centred (Dhawan, 2020).

Significantly, HEIs are familiar with online technologies which they only needed to expand because they were not starting from scratch with new and uncontested technological solutions (Czerniewicz, 2020). This implies that HEIs are required to not only increase their online and tech-enhanced pedagogical approaches, using technology more aptly and design teaching strategies suitable for particular situations, but also being mindful that technological choices will be formed in ways that will mirror prevailing variances, viewpoints and discourses (Murgatrotd, 2020 as cited in Ali, 2020).

An increase in tech-enhanced teaching opportunities will allow HEIs to look at the productive side of online learning technologies, thus bringing out innovations and digital developments. Thus, whilst HEIs are positioned to design flexible programs which may be technologically more accessible, students may get opportunities to practice technology (Huang et al., 2020). Fundamentally, the use of more tech-enhanced approaches may improve adaptability, critical thinking abilities as well as problem-solving skills, whilst HEIs may reap the benefits of time and location flexibility. When HEIs accelerate the speed of technology repetition and optimise practical application of online teaching, students from various backgrounds can be taught in innovative and inclusive ways (UNESCO, 2020).

\subsection{Teaching students with diverse backgrounds}

Globally, HEIs should be united in the promise to guarantee equitable and inclusive education as well as to support constant learning opportunities for individuals from different backgrounds (United Nations [UN], 2016). In this regard, HEIs have the daunting task accommodate and integrate social and cultural diversities, to ensure that thoughtful cultural approaches are embedded in their practices and to monitor and improve such practices in this respect (Feldman et al., 2018). Despite the afore-mentioned challenges, HEIs should play a strategic part in constructing a more sustainable and inclusive learning and teaching environment so that students (and preservice teachers in particular) are well prepared to appreciate and embrace diversity, grow inclusive learning settings and address several forms of segregation or relegation in scholastic settings (Cretu \& Morandau, 2020).

Initial Teacher Education Education programmes in HEIs should, therefore, equip preservice teachers with the required information, abilities, approaches and standards (Coates, Harris \& Warring, 2020) and use frames of reference, previous knowledge and diverse experiences to make learning opportunities more applicable and actual (Walton \& Rusznyak, 2019). Consequently, the construction of an inclusive social-emotional environment that may assist students to be more comfortable to express individual thoughts and experiences, specifically because they have contrasting cultural backgrounds and attainment levels (Harriott \& Martin, 2016).

\subsection{Preparing preservice through transformative inclusive learning modalities}

The reality of diversity in schoolrooms globally has been identified as, "One of the most challenging developments within education" (Lancaster \& Auhl, 2013, 363). In response to such an observation, HEIs have to provide an answer to this encounter by providing preservice teachers with the information necessary to promote transformative inclusive practices so that they will be able to teach in diverse classroom settings. The strength of a transformative inclusive pedagogy lies in its power to reduce the disparity of opportunity to learn, whilst it supports the ability to teach (Florian, 2015). In essence, HEIs should train preservice teachers how to enact transformative inclusive learning pedagogies in an ever-changing world. This paper uses a view by Florian and Black-Hawkins (2010) to explain that transformative inclusive learning pedagogies,

"seek to embed equitable access and opportunity for success within the classroom and curriculum. It is underpinned by a shift in pedagogical thinking from an approach that works for most learners existing alongside something different for those (some) who experience difficulties, towards one that involves providing rich learning opportunities that are sufficiently made for everyone" (p. 826).

The above explanation is applicable to the current online digital spaces that HEIs find themselves. For instance, it is imperative that HEIs consider the developing scope of digital technologies (Janssen et al. 2013, p. 474), requiring a constant reflection on preservice teachers' skills and desires and where required plan for professional learning opportunities in response to fast fluctuating educational settings. One way in which HEIs can prepare preservice teachers through transformative inclusive learning pedagogies is to teach them effective digital literacy skills, implying that they are taught a set of abilities to access the internet, discover and manage digital information and engage with virtual 
communication and information networks (Gilster, 1997 as cited in Falloon, 2020, 2450). Arguably, an understanding of digital and online information may be regarded as an inclusive view of digital literacy (Falloon, 2020).

Another way in which HEIs may prepare preservice teachers is to offer transformative learning opportunities which may stimulate the improvement of proficiency and confidence in new roles and relationships that may enable preservice teachers to bring about change in their learning and working environments (Tsimane \& Downing, 2020). For instance, HEIs can train preservice teachers how to use imaginative skills in that they learn how to create brainstorming situations and work as generators of new information and knowledge regarding inclusive practices (Llewellyn, 2016).

\section{Conclusion}

This paper asked the question: How may HEIs prepare preservice teachers to implement transformative learning pedagogies to become transformative change agents in multicultural higher learning contexts? We answered this question through our arguments that HEIs should strengthen their support to preservice teachers by empowering them how to utilise transformative inclusive learning pedagogies. We recommend that HEIs regard innovations and digital developments, the use of prior experiences and frames of reference, as well as digital literacy skills as ideal tools to prepare preservice teachers so that they will be ready to apply transformative inclusive learning pedagogies in the multicultural learning contexts within which they may function in the future.

\section{References}

Ali, W. (2020). Online and Remote Learning in Higher Education Institutes: A Necessity in light of COVID-19 Pandemic. Higher Education Studies, 10(3), 16-25.

Banks, J., \& Banks, C. (2004). Handbook of research on multicultural education. San Francisco, CA: Jossey-Bass.

Cheng, W., Cheng, Q., Yin, X., Zhuang, R., Berrada, K., Burgos, D., Chan, C., Chen, N. S., Cui, W., Hu, $X$. et al. (2020). Handbook on facilitating flexible learning during educational disruption: The Chinese experience in maintaining undisrupted learning in COVID-19 outbreak. Beijing: Smart Learning Institute of Beijing Normal University.

Coates, J.K., Harris, J., \& Waring, M. (2020). The effectiveness of a special school experience for improving preservice teachers' efficacy to teach children with special educational needs and disabilities. British Educational Research Journal, 46(5), 909-928.

Cretu, D.M., \& Morandau, F. (2020). Initial Teacher Education for Inclusive Education: A Bibliometric Analysis of Educational Research. Sustainability, 12(12), 4923. Retrieved March 24, 2021, from: https://doi.org/10.3390/su12124923

Czerniewicz, L. (2020). What we learnt from "going online" during university shutdowns in South Africa. Retrieved March 24, 2021, from: https://philonedtech.com/what-we-learnt-from-goingonline-during-university-shutdowns-in-south-africa/

Dhawan, S. (2020). Online Learning: A Panacea in the Time of COVID-19 Crisis. Journal of Educational Technology Systems, 49(1), 5-22.

Falloon, G. (2020). From digital literacy to digital competence: the teacher digital competency (TDC) framework. Education Technology Research and Development, 68, 2449-2472.

Feldman, A., Altrichter, H., Posch, P., \& Somekh, B. (2018). Teachers investigate their work (3rd ed.). London \& New York: Routledge.

Florian, L. (2015) Inclusive Pedagogy: A transformative approach to individual differences but can it help reduce educational inequalities? Scottish Educational Review, 47(1), 5-14.

Florian, L., \& Black-Hawkins, K. (2010). Exploring inclusive pedagogy. British Educational Research Journal, 37(5), 813-828.

Freire, P. (1970). Pedagogy of the Oppressed, trans. Myra Bergman Ramos. New York: Continuum.

Frenk, J., Chen, L., Bhutta, Z.A., Cohen, J., Crisp, N., Evans, T., \& Kistnasamy, B. (2010). Health professionals for a new century: transforming education to strengthen health systems in an interdependent world. The Lancet, 376(9756), 1923-1958.

Harriott, W.A., \& Martin, S.S. (2016). Using culturally responsive activities to promote social competence and classroom community. Teaching Exceptional Children, 37(1), 48-54.

Hoggan, C., Mãlkki, K., \& Finnegan, F. (2017). Developing the Theory of Perspective Transformation: Continuity, Intersubjectivity, and Emancipatory Praxis. Adult Education Quarterley, 67(1), 48-64.

Huang, R. H., Liu, D. J., Tlili, A., Yang, J. F., Wang, H. H., Zhang, M., Lu, H., Gao, B., Cai, Z., Liu, M., 
Janssen, J., Stoyanov, S., Ferrari, A., Punie, Y., Pannekeet, K., \& Sloep, P. (2013). Experts' views on digital competence: Commonalities and differences. Computers \& Education, 68, 473-481.

Kasworm, C., \& Bowles, T. (2012). Fostering transformative learning in higher education settings. In E. Taylor \& P. Cranton (Eds.), The handbook of transformative learning: Theory, research, and practice (388-407). San Francisco, CA: Jossey-Bass.

Lancaster, J., \& Auhl, G. (2013). Encouraging Pattern Language Development in a Preservice Inclusive Education Course: A Comparative Study. International Journal of Disability, Development and Education, 60(4), 363-381.

Llewellyn, S. (2016). Crossing the invisible line. De-differentiation of wake, sleep and dreaming may engender both creative insight and psychopathology. Conscious Cognition, 46, 127-147.

Mezirow, J. (1991). Transformative dimensions of adult learning. San Francisco, CA: Jossey-Bass.

Mezirow, J. (2003). Transformative learning as discourse. Journal of Transformative Education, 1(1), 58-63.

Mpungose, C.B. (2020). Emergent transition from face-to-face to online learning in a South African University in the context of the Coronavirus pandemic. Humanities \& Social Sciences Communications, 7(1), 1-9. Retrieved March 29, 2021, from: https://www.nature.com/articles/s41599-020-00603-x

Penprase, B.E. (2019). Accelerating Workforce Reskilling for the Fourth Industrial Revolution an Agenda for Leaders to Shape the Future of Education, Gender and Work. World Economic Forum: Geneva

Tsimane, T.A., \& Downing, C. (2020). Transformative learning in nursing education: A concept analysis. International Journal of Nursing Science, 7, 91-98.

UNESCO. (2020). COVID-19 Educational Disruption and Response. Retrieved March 24, 2021, from: https://en.unesco.org/covid19/educationresponse/

United Nations. (2016). Sustainable development goal 4: targets and indicators [webpage]. New York: UN. Retrieved March 29, 2021, from: https://sustainabledevelopment.un.org/sdg4\#targets

Walton, E., \& Rusznyak, L. (2019). Cumulative knowledge-building for inclusive education in initial teacher education. European Journal of Teacher education, 43(1), 18-37. 